\title{
KESELAMATAN PRODUK FARMASEUTIKAL DALAM PERUNDANGAN MALAYSIA DAN SYARIAH: SATU SOROTAN LITERATUR
}

\section{Safety Regulation on Pharmaceutical Product in Malaysian and Shariah Legislation: A Literature Review}

\author{
Nazatul Nabila Mohd Jalil \\ Master Candidate, Department of Shariah and Law, \\ Academy of Islamic Studies, \\ University of Malaya, 50603 Kuala Lumpur. \\ nazanabila91@siswa.um.edu.my. \\ Zalina Zakaria \\ Lecturer, Department of Shariah and Law, \\ Academy of Islamic Studies, \\ University of Malaya, 50603 Kuala Lumpur. \\ zalina_jsu@um.edu.my
}

\begin{abstract}
Consumer right to safety is one of the rights that has been recognised universally. The view of protecting the basic rights of consumer is widely accepted through the promulgation and effective enforcement of consumer protection policies and legislation. Product safety regulations are aimed to prevent dangerous products from reaching the market or the consumer and inform the consumer on how to use the products safely. At the same time, product safety regulations also protect consumers against unreasonable, unacceptable and preventable risks. In Islamic perspective, the concept of halalan tayyiban and maqasid shariah are the main indicator in product safety regulation. This article will review the literature on the concept of consumer protection and product safety regulation in Malaysian and Shariah legislation.
\end{abstract}

Keywords: product safety, halālan țayyiban, maqāṣid al-Sharī'ah. 


\section{PENDAHULUAN}

Kawalan kendiri (self-regulation) dalam proses penghasilan barang tidak mampu mengawal tindakan pengeluar secara efektif (C.J. Miller, Brian W.Harvey dan Deborah L.Parry, 1998: 23). Isu mengenai keselamatan produk ini kian menjadi perhatian masyarakat dan negara apabila terdapat pengguna yang mengalami kesakitan, kecederaan, dan kematian akibat daripada penggunaan produk yang cacat, bahaya dan berisiko. Contohnya statistik yang dikeluarkan oleh Penguatkuasa Kementerian Perdagangan Dalam Negeri, Koperasi dan Kepenggunaan pada Jun 2015, sebanyak 16,158 aduan diterima diseluruh negara berkaitan kepincangan produk yang terdapat di pasaran (Kementerian Perdagangan Dalam Negeri, Koperasi dan Kepenggunaan, Jun 2015: 84). Oleh itu, undang-undang keselamatan produk dan perlindungan pengguna merupakan instrumen yang wajar dalam melestarikan perlindungan pengguna yang mampan.

Manakala dari perspektif falsafah kepenggunaan Islam pula kepenggunaan perlulah berpaksikan kepada tauhid bagi memenuhi matlamat penciptaan manusia untuk beribadah kepada Allah SWT (Rohani Abd Rahim, 1992: 6). Justeru, kepenggunaan dalam Islam merupakan salah satu amanah dari Allah SWT. Selain itu, matlamat utama kepenggunaan Islam pula adalah untuk mencapai maqāsid syāriah (tujuan pensyariatan) iaitu mendatangkan kebaikan (maslahah) dan mengelak keburukan (mafsadah) di dunia dan di akhirat (Abdul Halim Abd Kadir, Nor Azzah Kamri dan Baharom Kassim, 2013: 1-27). Oleh itu, aspek keselamatan dan kualiti turut menjadi etika dan adab yang ditekankan dalam kepenggunaan Islam.

Artikel ini akan melihat sorotan literatur berkaitan keselamatan produk dan perlindungan pengguna. Sorotan literatur ini dibahagikan kepada beberapa tema bagi melihat perlindungan pengguna dan keselamatan produk yang terdapat di dalam perundangan sivil dan syariah. Oleh itu, sorotan kajian ini dibahagikan kepada empat tema iaitu undang-undang perlindungan pengguna dan keselamatan produk, undang-undang keselamatan ubat-ubatan, undangundang keselamatan ubat-ubatan di Malaysia, dan keselamatan produk dalam perspektif Islam.

\section{UNDANG-UNDANG PERLINDUNGAN PENGGUNA DAN KESELAMATAN PRODUK}

Revolusi perindustrian telah membawa perubahan besar dalam dunia pengusahaan dan penghasilan produk. Revolusi perindustrian menyebabkan pengeluar dan pengilang kurang peka terhadap keselamatan dan kualiti 
produk yang dikeluarkan. Oleh itu, wujudlah undang-undang pengguna untuk melindungi pengguna daripada produk yang berbahaya dan tidak berkualiti. Menurut Huffman (2010: 7-45), undang-undang perlindungan pengguna ini merupakan peraturan yang digubal untuk melindungi kepentingan pengguna di peringkat transaksi individu.

Brian W. Harvey dan Deborah L. Parry (2000: 1) pula menjelaskan bahawa undang-undang perlindungan pengguna dirangka bagi melindungi pengguna daripada produk dan perkhidmatan yang berbahaya dan cacat, penipuan dalam aktiviti pernigaan dan eksploitasi ekonomi oleh pengeluar. Manakala David Oughton and John Lowry (1997: 23) menegaskan bahawa undang-undang perlindungan pengguna ialah satu bentuk kawalan pemasaran dan perniagaan yang berpusat kepada kepentingan pengguna dengan melindungi pengguna daripada produk dan perkhidmatan yang tidak selamat dan berkualiti rendah serta melindungi mereka daripada penyataan palsu (false description) dan perbandingan harga (price comparison).

Perlindungan pengguna menjadi keperluan pada masa kini disebabkan oleh kejahilan pengguna itu sendiri yang berpunca daripada kemajuan teknologi maklumat dan komunikasi, inovasi sains dan teknologi serta penghasilan variasi produk yang rumit dan kompleks di pasaran pengguna (Rahmah Ismail, 2000: 60). Menurut Ahmad Sobri Jaafar (2004), pengguna juga perlu dilindungi kerana mereka sering menjadi mangsa apabila berlakunya kegagalan dalam sesebuah pasaran akibat daripada ketidakseimbangan kuasa tawar-menawar di pasaran disebabkan oleh kesukaran pengguna untuk mendapatkan maklumat yang tepat dan lengkap mengenai produk.

Selain itu, perlindungan pengguna ini juga diperlukan bagi melindungi pengguna daripada monopoli pasaran dan iklan-iklan yang berlebihan dan mengelirukan (Brian W.Harvey dan Deborah L.Parry, 1996: 19-23). Undangundang perlindungan pengguna perlulah bermatlamat untuk melindungi hakhak pengguna melalui penetapan standard bagi barang dan perkhidmatan; mewujudkan mekanisme untuk menerima, menyiasat dan mengambil tindakan berdasarkan aduan yang dibuat oleh pengguna; mengharamkan sebarang tindakan yang boleh mengganggu gugat hak pengguna; dan keperluan untuk memberikan maklumat berkaitan produk kepada pengguna (J.L. Goldring et al., 1993: 7).

Namun, undang-undang perlindungan pengguna memerlukan penguatkuasaan undang-undang yang berkesan bagi memastikan perlindungan pengguna yang holistik dan mampan (Molony Committee, 1962). Namun tindakan penguatkuasaan undang-undang tidak akan berkesan sekiranya tidak ada kerjasama daripada pihak kerajaan, pengeluar, dan pengguna 
memandangkan mereka adalah tiga entiti utama dalam pasaran pengguna (Mohd Iqbal S. dan Halimah A., 1999).

Undang-undang perlindungan penguna ini sebagaimana yang dikatakan oleh Lauren Krohn (1995: 4) merupakan hasil gabungan pelbagai bidang undangundang antaranya undang-undang jenayah, sivil, dan pentadbiran, tetapi fokus utama undang-undang ini adalah menyediakan peruntukkan undang-undang berkaitan keselamatan produk dan undang-undang liabiliti produk. Menurut Calabresi (1970: 73-96), undang-undang keselamatan produk dan undangundang liabiliti produk adalah satu set undang-undang yang saling melengkapi dalam menjamin keselematan pengguna dan mengurangkan kecederaan yang dialami oleh pengguna disebabkan oleh produk yang berbahaya. Namun begitu, Peter Cartwright (1995: 222-231) menyatakan bahawa undang-undang liabiliti produk mempunyai beberapa limitasi dalam memastikan barangan yang berada di pasaran adalah selamat untuk pengguna.

Limitasi-limitasi yang terdapat dalam undang-undang produk liabiliti menyebabkan undang-undang keselamatan produk menjadi satu keperluan bagi memastikan pengguna tidak terdedah kepada risiko-risiko produk yang berbahaya. Ini adalah kerana produk liabiliti hanyalah memfokuskan kepada membetulkan kerosakan dan kemudaratan yang telah berlaku dengan cara menuntut pampasan dan ganti rugi (Ibid.). Justeru, undang-undang liabiliti hanya akan digunapakai apabila kemudaratan dan kecelakaan telah berlaku kepada pengguna disebabkan produk yang berbahaya yang telah dikeluarkan oleh pengeluar. Manakala undang-undang keselamatan produk pula bersifat sebagai pencegah yang bermatlamat untuk mencegah dan mengelakkan barangan-barangan yang berbahaya daripada menembusi pasaran pengguna. Oleh kerana itu, undang-undang liabiliti produk dan undang-undang keselamatan produk saling diperlukan bagi menjamin perlindungan pengguna yang wajar.

Kajian sarjana sebelum ini mengenai teori perundangan keselamatan produk juga telah banyak dilaksanakan. Kebiasaaannya ekonomi, sosiologi dan politik merupakan antara aspek teori perundangan keselamatan produk yang dikaji oleh sarjana. Peter Ash (1988: 45) mengkaji mengenai undang-undang keselamatan produk dari perspektif ekonomi. Beliau menyatakan bahawa undang-undang keselamatan produk ini mempunyai sedikit kontroversi berkaitan peranan kerajaan dari aspek ekonomi. Ini kerana penggubalan dan penguatkuasaan undang-undang keselamatan produk akan menyekat kebebasan pasaran dan mengurangkan pertumbuhan ekonomi.

Di Malaysia, kajian mengenai undang-undang keselamatan produk semakin mendapat perhatian pengkaji. Penulisan berbentuk perbandingan perundangan 
dilaksanakan oleh pengkaji antaranya Rahmah Ismail \& Syed Sagoff Alsagoff (2010), dalam kajian mereka yang memberikan gambaran bahawa negara membangun terdedah kepada tindakan pihak industri yang tidak beretika yang menjadikan negara-negara membangun ini sebagai terminal lambakan barangan yang tidak mencapai standard piawaian keselamatan (2010).

Malangnya, keadaan ini juga diburukkan lagi dengan globalisasi dan kebebasan perdagangan tanpa sempadan dewasa ini. Natijahnya, daripada pemerhatian kajian tersebut jelas menggambarkan mengenai kepentingan undang-undang keselamatan produk dan perlindungan serta pelaksanaannya di dalam sesebuah negara membangun seperti Malaysia. Ini kerana, negara membangun seperti Malaysia menghadapi kemunduran dan masalah disebabkan kekurangan sumber, struktur, kemudahan teknikal dan kakitangan yang berkelayakan dalam pelaksanaan undang-undang keselamatan produk berbanding dengan negara maju seperti Amerika Syarikat dan Eropah sebagaimana hasil kajian perbandingan mengenai keselamatan produk kosmetik yang dijalankan oleh Zalina Zakaria (2012: 20-27). Selain itu, pemerhatian mengenai keselamatan produk di peringkat sebelum, semasa dan selepas pemasaran produk juga penting bagi melindungi keselamatan pengguna. Sebagaimana yang dijelaskan oleh Rahmah Ismail (2002: 72) bahawa undang-undang keselamatan produk dan perlindungan pengguna di setiap peringkat pemasaran produk merupakan dua perkara yang perlu ditangani secara serentak bagi memastikan pengguna tidak terdedah dengan produk yang berisiko dan berbahaya.

\section{UNDANG-UNDANG KESELAMATAN UBAT-UBATAN}

Pelbagai teknologi dalam penghasilan ubat-ubatan diperkenalkan bagi mengurangkan kesilapan dalam penghasilan ubat-ubatan. Hal ini terbukti daripada kajian Joseph Bubalo \& Bruce A. Warden (2014: 445-460) yang mendapati bahawa kemajuan teknologi bukan hanya dapat memudahkan proses ubat-ubatan dihasilkan malah dapat mengurangkan kesilapan serta dapat menjimatkan kos dalam penghasilan produk ubat-ubatan. Keselamatan ubat-ubatan menjadi antara bidang kajian yang tidak asing lagi di Barat, antaranya penulisan oleh Joseph Bubalo \& Bruce A Warden (2014: 445-460), Ming-Hseng Tsenga \& Hui-Ching (2014: 99-113), dan J. Y. Wang, C. H. Tsai \& S. W. Wang (2013: 1-5).

Namun kajian tersebut bukanlah kajian berbentuk perundangan keselamatan ubat-ubatan tetapi berkaitan sistem pengurusan ubat-ubatan berdasarkan kepada teknologi sains semasa. Contohnya penggunaan sistem kod QR (Quick 
Response Code), ${ }^{1}$ perkhidmatan web, senarai semak keselamatan, sistem telecare, dan farmakovigilans ${ }^{2}$ agar keselamatan ubat-ubatan yang dibekalkan kepada pengguna dapat ditingkatkan. Namun, aspek undang-undang berkaitan keselamatan, kualiti dan keberkesanan produk farmaseutikal tidak dibahaskan bersama. Kemajuan sains dan teknologi sahaja belum cukup untuk memberi jaminan bahawa setiap produk farmaseutikal yang berada di pasaran adalah selamat, berkualiti dan berkesan.

Ini disokong oleh Roseann B. Termini (2012: 87) yang menyatakan bahawa setiap jenis ubat-ubatan sama ada ubat-ubatan moden, generik, ${ }^{3}$ botanikal, ${ }^{4}$ tradisional, biologikal ${ }^{5}$ dan sebagainya memerlukan pengawasan di setiap peringkat bagi memastikan keselamatan penggunaannya oleh pengguna. Meskipun setiap negara mempunyai peruntukan undang-undang tersendiri berkaitan keselamatan produk ubat-ubatan, namun isu-isu keselamatan ubatubatan ini masih menjadi isu global tanpa sempadan. Walau bagaimanapun, kajian mengenai undang-undang keselamatan ubat-ubatan banyak tertumpu kepada ubat-ubatan herba dan traditional, antaranya kajian oleh Melissa Coutino (2009: 442-447), Richard Griffith \& Cassam Tengnah (2014: 61-77), dan Frank Xiaoqing Liu \& Warren Salmon (2010/2011: 123-140).

Peningkatan permintaan terhadap produk tradisional dan herba menjadi faktor utama peningkatan kajian perundangan berkaitan undang-undang keselamatan produk ini. J.B. Calixto (2000: 179-189) dalam kajian beliau membuktikan bahawa industri ubat-ubatan herba dilihat lebih pesat

1 Quick Response Code adalah satu kod matrik dua dimensi yang mana kod tersebut boleh dibaca oleh mesin pengimbas kod yang membolehkan pengguna mendapatkan info berkaitan keselamatan, kualiti dan keberkesanan ubat-ubatan dengan pantas dan mudah.

2 Pharmacovigilance adalah aktiviti berkaitan proses mengenalpasti, menilai, memahami dan menghalang kesan buruk dan merbahaya atau apa-apa masalah berkaitan ubat-ubatan.

3 Ubat generik ialah ubat yang dikeluarkan oleh syarikat-syarikat lain setelah tempoh paten yang diberikan kepada syarikat-syarikat yang mengeluarkan ubat original telah luput. Kandungan ubat generik adalah sama dengan ubat original. Bagaimanapun ia tidak boleh diberi nama yang sama, kerana setiap nama adalah unik dan telah dipatenkan.

4 Ubat-ubatan juga dikenali sebagai ubat-ubatan herba atau phytomedicine yang berasas tumbuhan herba, dan aromatik, ia didefinasikan sebagai kegunaan seluruhan tumbuh-tumbuhan atau sebahagian dari tumbuh-tumbuhan untuk mencegah atau merawat, mengawal dan mengurangkan kesakitan dan penyakit.

5 Ubat-ubatan yang dihasilkan daripada penggabungan teknologi DNA dan ditulenkan daripada benda hidup. 
berkembang berbanding ubatan-ubatan lain dan pasaran ubat-ubatan herba mencapai kira-kira \$7 billion di Eropah dan \$5 billion di Amerika Syarikat. Justeru, dalam kajian yang akan dijalankan ini tidaklah hanya membincangkan isu-isu berkaitan keselamatan ubat-ubatan herba dan traditional sahaja, tetapi turut melihat isu-isu keselamatan produk farmaseutikal ini secara menyeluruh tanpa memfokuskan kepada mana-mana ubat-ubatan tertentu agar kajian ini menjadi lebih komprehensif.

\section{UNDANG-UNDANG KESELAMATAN UBAT-UBATAN DI MALAYSIA}

Di Malaysia, BPFK di bawah KKM banyak mengeluarkan majalah dan laporan tahunan berkaitan keselamatan produk farmaseutikal. Isu-isu dan statistik mengenai keselamatan ubat-ubatan dipaparkan dalam setiap keluaran. Maklumat dan isu yang telah dinyatakan dalam laporan kementerian ini menyebabkan kajian mengenai keselamatan produk ubat-ubatan semakin menggalakkan. Namun, kebanyakan kajian ini bukanlah menjurus kepada peruntukkan undang-undang dan polisi berkaitan keselamatan produk ubatubatan di Malaysia, malah hanya menilai dari sudut kesedaran orang awam mengenai keselamatan ubat-ubatan. Contohnya kajian yang dijalankan oleh Saranyaa \& Bin Seng Low (2014: 1-6) yang mendapati bahawa masyarakat awam di Malaysia masih kurang kesedaran dan pengetahuan mengenai isu-isu keselamatan ubat-ubatan sama ada ubatan tersebut generik, palsu, campuran herba dan racun berjadual, tidak berdaftar, dan tercemar.

Perkembangan teknologi maklumat dan komunikasi juga memberi kesan kepada industri farmaseutikal di Malaysia. Kini, pengguna mengunakan rangkaian telekomunikasi dan internet untuk mendapatkan produk farmaseutikal. Oleh kerana itu, kajian yang dijalankan oleh Puteri Nemie Jahn Kassim (2008: 15-23) mengaitkan kemajuan dalam dunia komunikasi dengan industri farmaseutikal. Isu keselamatan ubat-ubatan dan pengiktirafan pengamal perubatan, iklan produk farmaseutikal, dan hak kerahsiaan maklumat pesakit bagi produk farmaseutikal yang dijual dalam talian (e-medicine) dibahaskan secara terperinci dalam kajian beliau. Namun, perbincangan hanyalah mengenai ubat-ubatan yang dipasarkan di atas talian dan melalui kajian beliau juga turut menyentuh topik ini untuk dihubungkan dengan kecuaian dalam perubatan. Beliau turut menjelaskan bahawa e-medicine ini memberi cabaran dari sudut perundangan terutama kepada pihak kehakiman dalam kes-kes berkaitan kecuaian dalam perubatan.

Justeru, penelitian yang lebih jelas dan mendalam akan dilaksanakan mengenai isu undang-undang keselamatan produk ubat-ubatan di Malaysia 
kini bagi melihat sejauh mana produk farmaseutikal di Malaysia ini selamat untuk pengguna dan bagaimana peranan undang-undang keselamatan produk ubat-ubatan dalam melindungi pengguna daripada ubat-ubatan yang tidak selamat dan memudaratkan.

\section{KEPENGGUNAAN DAN KESELAMATAN PRODUK DALAM ISLAM}

Menurut Rohani Abd Rahim (1992: 6) konsep berkaitan kepenggunaan tidaklah dijelaskan secara terperinci di dalam al-Quran mahupun Hadis, namun perkataan-perkataan yang berbau perintah kepada "perilaku untuk menggunakan" wujud dalam banyak bahagian al-Quran. Misalnya, perkataan seperti belanjalah, makanlah, pakailah, berikanlah, tunggangilah. Menurut Syariah, pengguna diberi kebebasan sepenuhnya dalam menggunakan sesuatu barangan atau perkhidmatan untuk mendapatkan kesejahteraan dan keselesaan hidup (Noor 'Ashikin Hamid, Nur Amani Pauzai \& Shariffah Nuridah Aishah, 2011: 1-20). Namun bagi melindungi pengguna, Islam menggariskan adab dan peraturan yang lengkap dalam menjalankan urusniaga secara adil (Nurshuhaida Abdul Razak \& Siti Zaiton Mohd Dali, 2012).

Selain itu, tauhid menjadi tonggak yang mendasari falsafah kepenggunaan dalam Islam (Abdul Halim Abd Kadir, Nor 'Azzah Kamri \& Baharom Kassim, 2013: 1-27). Oleh itu, falsafah kepenggunaan Islam mempunyai matlamat untuk memelihara kemaslahatan pengguna di dunia dan akhirat. Justeru, terdapat etika dan adab turut digariskan Islam untuk merealisasikan matlamat kepenggunaan Islam. Antara etika dan adab tersebut adalah keadilan, kebersihan, keselamatan, kualiti, kesederhanaan, kebijaksanaan, kebertanggungjawaban dan keberkatan (Ibid.).

Namun konsep keselamatan produk dalam Islam tidak terdapat perbahasannya secara terperinci dalam kitab-kitab fiqh klasik mahupun kontemporari. Kajian mengenai konsep keselamatan produk dalam Islam juga tidak dibincangkan dengan spesifik oleh sarjana-sarjana sebelum ini. Namun, keselamatan produk ini dibincangkan secara ringkas dan tidak langsung dalam bab-bab tertentu kitab fiqh, antaranya dalam bab makanan, jual beli dan perubatan. Dalam kajian ini, konsep halālan tayyiban akan dikaji bagi melihat prinsip-prinsip keselamatan produk yang terdapat dalam Islam. Pemilihan konsep halālan tayyiban ini adalah kerana konsep ini merupakan indikator utama dalam menentukan keselamatan, kualiti dan kebersihan produk dalam Islam, sama ada produk makanan, minuman, kosmetik, farmaseutikal, mahupun produk perbankan. Oleh itu, konsep ini dilihat merupakan konsep 
yang paling sesuai dan tepat untuk kajian ini bagi menganalisis prinsip-prinsip keselamatan produk yang telah digariskan oleh Islam.

Al-Qarạ̣āwī (1994: 6) menyatakan bahawa halal adalah sesuatu yang diharuskan, yang tiada ikatan larangan padanya dan diizinkan oleh syarak untuk melakukannya. Al-Jurjanī (2000: 119) pula membahagikan halal kepada dua pengertian. Pertama, merujuk kepada keharusan menggunakan sesuatu untuk keperluan jasmani contohnya makanan, minuman dan ubat-ubatan. Kedua, halal berkaitan keharusan sesuatu perbuatan atau tindakan seperti memakan, meminum, membelanjakan dan sebagainya. Manakala tayyiban ini diistilahkan dengan definisi yang berbeza melihat kepada konteks ayat alQuran. Oleh itu, ulama' berselisih pendapat dalam mendefinisikan țayyiban dari aspek istilah. Terdapat lima pandangan ulama' dalam mendefinisikan frasa tayyiban dari sudut istilah.

Pandangan pertama, mendefinisikan tayyiban sebagai halal, kerana setiap yang dihalalkan oleh Allah SWT adalah bersifat baik (tayyib), manakala yang diharamkan oleh Allah SWT adalah buruk dan jijik (khaba'ith). Pandangan ini diutarakan oleh Imam Mālik (2013M/1434H: 144), al-Șabunī (1999: 112), Imam al-Baghwī (2002M/1432H: 82), dan al-'Asimin (2011H/1432H: 81). Manakala, pandangan kedua pula dilontarkan oleh al-Alusī (2000: 177), dan Imam al-Baghwī (2002M/1432H: 80-81) yang berpendapat bahawa tayyiban merujuk kepada sifat sesuatu yang bersih dan suci (الطاهر), iaitu bersih daripada najis, perkara-perkara syubhah dan kekotoran. Dalam konteks ini, al-Dibyan (2002) menyatakan bahawa (الطاهر) membawa maksud bersih sesuatu perkara daripada najis sama ada najis yang hakiki atau hukmi, sama ada sesuatu perkara itu berkaitan dengan solat, pakaian, badan, tempat, makanan, dan sebagainya.

Pandangan ketiga pula berpendapat bahawa tayyiban itu sesuatu yang dianggap baik dan suci oleh Bangsa Arab, begitu juga dengan khaba 'ith yang merujuk kepada sesuatu yang dianggap keji dan jijik oleh masyarakat Arab. Ini merupakan pandangan yang dikeluarkan oleh mazhab Shāfi ‘', Hanafī dan Hanbali (2002M/1432H: 358). Pandangan keempat daripada al-Rāzí (1981: 74), al-Qurțubi, dan Imam al-Shāfi'ì mendefinisikan tayyiban itu sebagai sesuatu yang lazat dan tidak diharamkan di dalam al-Quran dan Hadis. Pandangan kelima pula menyatakan bahawa tayyiban adalah perkara yang tidak memudaratkan agama, badan dan akal. Justeru, perkara yang tayyiban itu mestilah memberi kemaslahatan (kebaikan) kepada agama, badan dan akal. Ini merupakan pandangan Ibn Taymiyyah (1908: 234), Ibn 'Ashūr (1984: 191) dan Ibn Kathīr (2004M/1424H: 287) mengenai frasa țayyiban.

Justeru, dalam Islam produk yang selamat bukan hanya perlu suci, bersih, dan menyihatkan, malah terhindar daripada perkara-perkara yang berbahaya, memabukkan, najis, dan menepati konsep ḥalālan țayyiban. Selain itu, dalam 
konsep maqāșid al-Syarī'ah telah menetapkan bahawa Islam memelihara lima perkara asas kemaslahatan manusia yang meliputi agama, diri, akal, keturunan dan harta. Oleh itu, sesuatu yang boleh mengancam dan memusnahkan lima nilai utama (al-kuliyyāt al-khams) ini perlu dihilangkan dan dihapuskan. Begitu juga dalam penggunaan produk di dalam Islam, produk yang boleh mengancam dan memusnahkan salah satu daripada lima nilai utama (al-kuliyyāt al-khams) ini dikira tidak sah penggunaannya dalam Islam. Sama ada produk tersebut merupakan produk makanan, minuman, farmaseutikal, kosmetik, mahupun produk perbankan. Oleh itu, produk yang selamat berdasarkan kepada Syariah adalah produk yang selamat penggunaannya terhadap agama, diri, akal, keturunan dan harta serta menepati konsep halālan țayyiban.

\section{KESIMPULAN}

Hasil daripada analisis tersebut mendapati bahawa sejarah undang-undang perlindungan pengguna membuktikan bahawa kawalan kendiri (selfregulation) tidak lagi mampu untuk melindungi pengguna daripada produk yang berbahaya, berisiko, dan cacat di pasaran kini. Oleh itu, undang-undang keselamatan produk merupakan salah satu cabang undang-undang perlindungan pengguna yang dilihat sesuai untuk memastikan kelestarian hak keselamatan pengguna pada era globalisasi ini. Ini kerana undang-undang keselamatan produk ini bersifat sebagai pencegah yang bermatlamat untuk mencegah dan mengelakkan produk yang berbahaya daripada menembusi pasaran pengguna.

Manakala dari sudut Syariah secara umumnya, tiada perbahasan secara terperinci berkaitan konsep keselamatan produk dalam Islam dibuat oleh ulama' silam mahupun kontemporari. Namun begitu, perbincangan ulama berkaitan konsep halālan țayyiban dan maqāșid al-Syarī'ah dikaitkan dengan konsep keselamatan produk. Oleh itu konsep halālan țayyiban dan maqāṣid alSyarīah merupakan indikator yang digunakan dalam penentuan keselamatan produk dalam Islam. Hasil analisis terhadap konsep halälan țayyiban dan maqāșid al-Syarī'ah dapat diringkaskan bahawa konsep keselamatan produk dalam Islam ini menggariskan bahawa setiap produk yang selamat mestilah halal, tidak memudaratkan, tidak berbahaya kepada diri (nyawa) dan akal.

\section{RUJUKAN}

'Imad al-Dīn Abī al-Fidā' Ismā'il Ibn Kathīr al-Qurashi al-Dimashqi (2004M/1424H). Tafsìr al-Qur'ān al- 'Ażìm Ibn Kathīr. Riyāḍ: Dār alSalām li al-Nasyar wa al-Tawzi`. 
Abdul Halim Abd Kadir, Nor 'Azzah Kamri dan Baharom Kassim (2013). Maqasid Syariah: Isu Kepenggunaan, Realiti dan Cabaran. Selangor: Persatuan Ulama’ Malaysia.

Abī al-Ḥasan 'Alī Ibn Muhammad Ibn 'Alī al-Husaynī al-Jurjanī (2000). alTa 'rifat. Beirūt: Dār al-Kutub al-'Ilmiyyah.

Ab̄̄ Muḥammad al-Husin bin Mas'ūd al-Baghwī (2002M/1432H). Tafsīr alBaghwī. Beirūt: Dār Ibn Hazm.

Ab̄̄ 'Umar Dibyan bin Muḥammad al-Dibyan (2002). Mawsū'ah al-Ahkām alTahārah al-Miyaah al-Aaniyah. Riyāḍ: Maktabah al-Rasyid Nashirūn.

Aḥmad Ibn 'Abd al-Halim Ibn Taymiyyah (1908). Kitāb Majmū' al-Fatawā. Qāhirah: Matba'at Kursiyatan.

Ahmad Sobri Jaafar (2004). "Kedudukan Pengguna dalam Komuniti Pasca Modenisme: Cabaran bagi Malaysia." Seminar Antarabangsa Nilai dalam Komuniti Pasca Modenisme (CIVIC 2004), Jabatan Pengajian Umum, Fakulti Sains Kognitif \& Pendidikan, Universiti Utara Malaysia. 4-6 September 2004.

Al-Sabuni (1999). Zawa al-Bayān Tafsīr Ayat al-Ahkām min al-Qur'ān. Qāhirah: Dār al-Șabunī.

Brian W. Harvey \& Deborah L. Parry (2000). The Law of Consumer Protection and Fair Trading. London: Butterworths.

Brian W.Harvey \& Deborah L. Parry (1996). Consumer and Trading Law Text, Cases and Materials. London: Butterworths.

Cartwright, P. (1995). "Product Safety and Consumer Protection," The Modern Law Review, vol. 58 (2), 222-231.

David Oughton \& John Lowry (1997). Textbook on Consumer Law. London: Blackstone Press Limited.

Fakhr al-Dīn al-Razī (1981). Mafātiḥ al-Ghā'ib. Beirūt: Dār al-Fikr.

Frank Xiaoqing Liu \& Warren Salmon (2010/2011). "Herbal Medicine Regulation in China, Germany, and the United States." Integrative Medicine, vol. 9 (6), 123-140.

Guido Calabresi (1970). The Cost of Accident: A Legal and Economic Analysis. New Haven: Yale University Press.

Huffman Max (2010). "Bridging the Divide? Theories for Integrating Competition Law and Consumer Protection." European Competition Journal, vol. 6 (1), 7-45.

Ibn 'Ashūr (1984). al-Tahrīr wa al-Tanwīr. Tunisia: al-Dār al-Tunisiyyah li al-Nashar. 
J. Y. Wang, C. H. Tsai \& S. W. Wang (2013). "Using Telecare System to Construct Medication Safety Mechanisms for Remote Area Elderly." Journal of Chemical and Pharmaceutical Research, vol. 5 (11), 1-5.

J. B. Calixto (2000). "Efficacy, Safety, Quality Control, Marketing and Regulatory Guidelines for Herbal Medicines (Phytotherapeutic Agents)." Brazilian Journal of Medical and Biological Research, vol. 33, 179-189.

J.L. Goldring et al. (1993). Consumer Protection Law in Australia. London: Butterworths.

Joseph Bubalo \& Bruce A Warden (2014). "Does Applying Technology throughout the Medication Use Process Improve Patient Safety with Antineoplastics?.” Journal of Oncology Pharmacy Practice, vol. 20 (6), 445-460.

Lauren Krohn (1995). Consumer Protection and the Law A Dictonary. Carlifornia: ABC-CLIO Inc.

Melissa Coutino (November 2009). "Legal and Regulatory Review the Regulation of Herbal Medicine." Journal of Management \& Marketing in Healthcare, vol. 2 (4), 442-447.

Ming-Hseng Tsenga \& Hui-Ching (2014). "A Cloud Medication Safety Support System Using QR Code and Web Services for Elderly Outpatients." Technology and Health Care, vol. 22, 99-113.

Mohd Iqbal S \& Halimah A (1999). "Consumer Protection: A Holistic Approach.” MACFEA IV. Seminar Tahunan Universiti Kebangsaan Malaysia, Ogos 1999.

Muḥammad bin 'Alī bin Muḥammad al-Syawkanī (2013M/1434H). Fath alQādir al-Jāmi ' bayna funna al-Riwāyah wa al-Dirāyah (Qāhirah: Dār al-Rad al-Jadīi).

Muḥammad bin Șāliḥ al-A'simin (2011H/1432H). Tafsìr al-Qur'ān al-Karīm Sūrah al- Mã'idah. Mamlakah al-'Arabiyyah al-Saudiyyah: Dār Ibn alJawzī.

Noor 'Ashikin Hamid, Nur Amani Pauzai \& Shariffah Nuridah Aishah (2011). "Konsep Kepenggunaan Mengikut Syariah dan Aplikasinya dalam Undang-Undang Malaysia.” KANUN, 1-20.

Nurshuhaida Abdul Razak \& Siti Zaiton Mohd Dali (2012). "Perbezaan Analisis Kepenggunaan Menurut Ekonomi Konvensional dan Ekonomi Islam.” Persidangan Kebangsaan Ekonomi Malaysia ke VII (PERKEM VII) Transformasi Ekonomi dan Sosial Ke Arah Negara Maju, Ipoh, Perak, 4-6 Jun 2012. 
Peter Asch (1988). Safety Regulation. London: Oxford University Press.

Puteri Nemie Jahn Kassim (2008). "E-Medicine in Malaysia: Legal and Ethical Challenges." Current Law Jurnal, 15-23.

Rahmah Ismail (2000). "Keselamatan Produk dan Perlindungan Pengguna." Jurnal Undang-Undang dan Masyarakat, vol. 4, 60.

Rahmah Ismail (2002). "Keselamatan Produk Pengguna: Perlindungan ke Atas Keselamatan Pengguna di Peringkat Sebelum, Semasa, dan Selepas Pemasaran Produk." Tesis Kedoktoran, Universiti Malaya. Kuala Lumpur.

Richard Griffith \& Cassam Tengnah (2014). "Regulation of Herbal Medicines." British Journal of Community Nursing, vol. 15 (9), 61-77.

Rohani Abd Rahim (1992). "Konsep Syariah dan Undang-undang Mengenai Kepenggunaan.” Seminar Syariah dan Common Law di Malaysia, Pusat Islam, Kuala Lumpur, 16-17 Mei 1992.

Roseann B. Termini (2012). Food and Drug Law Federal Regulation of Drugs, Biologics, Medical Devices, Foods, Dietary Supplements, Cosmetics, Veterinary and Tobaco Products. USA: Forti Publication.

Saranyaa Silvanathan \& Bin Seng Low (2014). "Current Public Awareness on the Safety of Traditional and Complementary Medicines (T\&CM) in Malaysia." European Journal of Integrative Medicine, vol. 30, 30.e130.e6.

Yūsuf al-Qaraḍāwī (1994). al-Halāl wa al-Harām. Beirūt: Maktabah al-Islāmī.

Zalina Zakaria (2012). "Cosmetic Safety Regulation A Comparative Study of Europe, the USA, and Malaysia.” Thesis Ph.D, University of Manchester, United Kingdom. 
Journal of Shariah Law Research (JSLR) 